\title{
REVIEW
}

\section{Hydrogen peroxide in regulation of plant metabolism: Signalling and its effect under abiotic stress}

\author{
T.A. KHAN", M. YUSUF ${ }^{* *}$, and Q. FARIDUDDIN ${ }^{* * *++}$ \\ College of Life Science and Technology, Huazhong Agricultural University, Wuhan-430070, Hubei, China* \\ Department of Biology, College of Science, United Arab Emirates University, P.O. Box: 15551, Al Ain, Abu Dhabi, UAE** \\ Plant Physiology and Biochemistry Section, Department of Botany, Aligarh Muslim University, Aligarh-202002, India***
}

\begin{abstract}
In plants, hydrogen peroxide $\left(\mathrm{H}_{2} \mathrm{O}_{2}\right)$ acts as a signalling molecule that facilitates various biochemical and physiological processes. $\mathrm{H}_{2} \mathrm{O}_{2}$ is a versatile molecule, involved in several cellular processes both under stress and stress-free conditions. In regulating plant metabolism under stress conditions, exogenous application of $\mathrm{H}_{2} \mathrm{O}_{2}$ also plays a pivotal role which is manifested in improved growth, photosynthetic capacity, and antioxidant protection. Abiotic stress is an inevitable environmental factor that extensively affects and reduces growth, quality, yield, and productivity of plants. Several signalling pathways involved in $\mathrm{H}_{2} \mathrm{O}_{2}$-mediated stress and defense responses have been extensively studied and there is ample scope of additional research that could further clarify the mechanism and modulating factors which regulate these pathways. An attempt has been made to dissect the role of $\mathrm{H}_{2} \mathrm{O}_{2}$ under low temperature stress and how it affects plant growth and development, photosynthetic capacity, regulation of antioxidant system, and signalling.
\end{abstract}

Additional key words: antioxidants; hydrogen peroxide; low temperature; photosynthesis; reactive oxygen species; signalling.

\section{Introduction}

Hydrogen peroxide $\left(\mathrm{H}_{2} \mathrm{O}_{2}\right)$ plays diverse roles in plants and acts as a signalling molecule. In the past two decades, evidence has been accumulating to address involvement of $\mathrm{H}_{2} \mathrm{O}_{2}$ in stress responses in plants; but how it interacts with phytohormones and the ways how signals are involved in biological processes remain fragmentary and still to be unravelled in detail. $\mathrm{H}_{2} \mathrm{O}_{2}$ mediates complex biological functions in plants because of its properties of free radical, small size, and high diffusibility (Leshem et al. 1998). In last ten years, various researchers tried to study the role of $\mathrm{H}_{2} \mathrm{O}_{2}$ as a signalling molecule. Because of its low reactivity compared to other types of reactive oxygen species (ROS), it has relatively long-life span and small size of $\mathrm{H}_{2} \mathrm{O}_{2}$ molecules is very helpful to cross biological membranes, facilitating signalling functions (Noctor et al. 2014). ROS may interact selectively with a target molecule that perceives the increase of ROS concentration and translates this information into signals that direct the plant responses to stress. ROS would be ideally more suited to act as such signaling molecules. There are several mechanisms for ROS production, some of which are rapid and controllable, and there are numerous mechanisms for rapid removal of ROS (Apel and Hirt 2004). The antioxidant systems, including detoxifying enzymes, play a pivotal role in regulating the $\mathrm{H}_{2} \mathrm{O}_{2}$ concentration (Noctor and Foyer 1998). Thus, antioxidant enzymes are emerging as key regulators of the multitude of pathways that respond to $\mathrm{H}_{2} \mathrm{O}_{2}$. In fact, both the production and scavenging

Received 20 July 2017, accepted 9 March 2018, published as online-first 21 June 2018.

${ }^{+}$Corresponding author; email: qazi farid@yahoo.com

Abbreviations: APX - ascorbate peroxidase; $C_{\mathrm{i}}$ - internal $\mathrm{CO}_{2}$ concentration; $\mathrm{CAT}$ - catalase; DHAR - dehydroascorbate reductase; $g_{\mathrm{s}}$ - stomatal conductance; GPX - glutathione peroxidase; GR - glutathione reductase; MDHAR - monodehydroascorbate reductase;

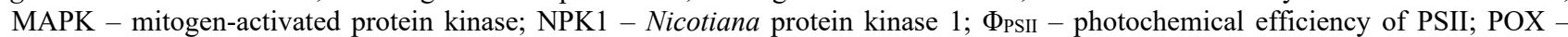
peroxidase; $P_{\mathrm{N}}$ - net photosynthetic rate; qP - photochemical quenching coefficient; ROS - reactive oxygen species; SOD - superoxide dismutase; SPAD - soil and plant analysis development.

Acknowledgements: The authors gratefully acknowledge financial support provided by the Council of Science and Technology, Uttar Pradesh [Project No. CST/D-615], India. 
of $\mathrm{H}_{2} \mathrm{O}_{2}$ in plant cells seems to be an integrated network that are responsible for triggering biological responses. However, $\mathrm{H}_{2} \mathrm{O}_{2}$ plays a versatile role in plants at low concentration; it acts as a signalling molecule and is also involved in the mitigation of numerous abiotic and biotic stresses (He et al. 2009, Mittler et al. 2011, Dietz et al. 2016). At higher concentrations, it induces the onset of cell death (Gechev and Hille 2005, Karuppanapandian et al. 2011, Bhattacharjee 2012). It plays an important role in plant cell wall reinforcement (cross-linking of cell wall structural proteins, lignification), production of phytoalexin, and resistance augmentation against diverse stresses (Gill and Tuteja 2010, Ahmad 2014). $\mathrm{H}_{2} \mathrm{O}_{2}$ is a key regulator in a broad range of physiological and biological processes such as germination and seedling growth (Wahid et al. 2008), photosynthesis (Noctor and Foyer 1998, Fariduddin et al. 2014, Khan et al. 2015, Hasan et al. 2016), stomatal movement, cell growth, and development (Deng et al. 2012), antioxidant systems (Khan et al. 2015, 2016, Hasan et al. 2016), and senescence (Peng et al. 2005). Therefore, it has been reported that the endogenous content of $\mathrm{H}_{2} \mathrm{O}_{2}$ depends on its production rates and utilization by antioxidant systems (Hung et al. 2005, Terzi et al. 2014). It has been described that $\mathrm{H}_{2} \mathrm{O}_{2}$ plays pivotal roles in modulating defense response of plants to diverse environmental stresses, such as salt stress (Li et al. 2011, Ashfaque et al. 2014), oxidative stress (Morita et al. 1999, Iseri et al. 2013), nickel stress (Khan et al. 2016), copper stress (Guzel and Terzi 2013, Fariduddin et al. 2014), heat stress (Wang et al. 2014), and chilling stress (Yu et al. 2003, Wang et al. 2010). In addition to this, exogenous application of $\mathrm{H}_{2} \mathrm{O}_{2}$ could be an effective approach for enhancing stress tolerance and improving productivity of crop plants under various abiotic stresses.

\section{Role of hydrogen peroxide in plant growth and development}

$\mathrm{H}_{2} \mathrm{O}_{2}$ is involved in many growth and developmental processes of plants, including root gravitropism and root system development (Ma et al. 2014, Hernandez-Barrera et al. 2015), stomatal movement, cell growth and development (Deng et al. 2012), formation of adventitious roots (Dunand et al. 2007), cell wall development (Carol and Dolan 2006), stomatal aperture regulation (Ge et al. 2015), and programmed cell death (Van Breusegem and Dat 2006, Cheng et al. 2015, Vavilala et al. 2015). Generally, $\mathrm{H}_{2} \mathrm{O}_{2}$ was used as a stimulant for inducing germination. Soaking seeds in $\mathrm{H}_{2} \mathrm{O}_{2}$ improved their germination in many plants, including barley, spinach, camphor, almond, and Zinnia elegans, Panicum virgatum, Andropogon gerardii, and Sorghastrum nutans (Chen and Lin 1994, Fontaine et al. 1994, Ogawa and Iwabuchi 2001, Sarath et al. 2007, Zeinalabedini et al. 2009, Barba-Espin et al. 2011). It has been shown that presown seed primed with $\mathrm{H}_{2} \mathrm{O}_{2}$ improved seed quality, resulting in better germination performance and greater vigour, while moderately abolishing aging effects on seeds (Wojtyla et al. 2016). Recently, Hasan et al. (2016) reported that foliar application of $\mathrm{H}_{2} \mathrm{O}_{2}$ increased growth parameters in Vigna unguiculata. Low concentration of $\mathrm{H}_{2} \mathrm{O}_{2}$ positively affected the adventitious root growth of marigold and sweet potato seedlings (Deng et al. 2012, Liao et al. 2012). Several plant hormones have been documented to interact with $\mathrm{H}_{2} \mathrm{O}_{2}$ during germination and early plant growth (Barba-Espin et al. 2010). The encouraging effect of $\mathrm{H}_{2} \mathrm{O}_{2}$

\section{Physiological roles of hydrogen peroxide}

\section{Hydrogen peroxide and photosynthesis}

Photosynthesis is the main source of carbon assimilation in plants. Increasing either photosynthetic efficiency or total plant photosynthetic capacity (delaying leaf senescence) results in the enhanced production of photoassimilates (van Camp 2005). It has been established that on seed germination could be due to scavenging of $\mathrm{H}_{2} \mathrm{O}_{2}$ which resulted in higher production of $\mathrm{O}_{2}$ required for mitochondrial respiration and metabolic activities in spinach (Katzman et al. 2001). Another explanation is that $\mathrm{H}_{2} \mathrm{O}_{2}$ is helpful in cracking hard seeds, permitting them to interact with water (Chen and Lin 1994). On the other hand, the pericarp and seed coat often contain phenolic compounds and alkaloids, which inhibit seed germination (Tao and Buta 1986, Bhattacharyya et al. 1999); these can be oxidized by $\mathrm{H}_{2} \mathrm{O}_{2}$ (Ogawa and Iwabuchi 2001). It has been suggested that NADPH oxidases are involved in the production of ROS during seed germination (Liu et al. 2007) and in breaking its dormancy (Oracz et al. 2009). Likewise, hydroxyl radical $\left(\mathrm{OH}^{\circ}\right)$-mediated cell wall loosening during seed germination and seedling growth have been reported (Müller et al. 2009). Moreover, treatment with $\mathrm{H}_{2} \mathrm{O}_{2}$ during early stage of plants also generated positive effect on germination that, without $\mathrm{H}_{2} \mathrm{O}_{2}$ treatment, was delayed by temperature stress (Çavusoglu and Kabar 2010). Treatment of seeds with $\mathrm{H}_{2} \mathrm{O}_{2}$ overcame the delay in germination induced by salt and temperature stress. The proteomic analysis indicated that $\mathrm{H}_{2} \mathrm{O}_{2}$ induced the expression of proteins related to plant signalling and development (Barba-Espin et al. 2010). Therefore, the redox state could be modulated by $\mathrm{H}_{2} \mathrm{O}_{2}$ corroborated with the expression of proteins involved in signalling and development during the early stage of seedling growth.

$\mathrm{H}_{2} \mathrm{O}_{2}$ affects the net photosynthetic rate and the related attributes in plants (Fariduddin et al. 2014, Khan et al. 2015, Hasan et al. 2016). Khandaker et al. (2012) also noted that exogenous application of $\mathrm{H}_{2} \mathrm{O}_{2}$ increased photosynthetic rates and dry matter content of the leaves in wax apple under field conditions. There is a number of 
reports available where the effects of $\mathrm{H}_{2} \mathrm{O}_{2}$ on photosynthesis have been examined but diversity exists among these observations (Table 1).

The reason for the $\mathrm{H}_{2} \mathrm{O}_{2}$-mediated increase in photosynthetic efficiency could be due to the fact that $\mathrm{H}_{2} \mathrm{O}_{2}$ treatments increased the maximum carboxylation rate of Rubisco $\left(\mathrm{V}_{\mathrm{cmax}}\right)$ and initial Rubisco activity, but had no effects on the total activity of Rubisco. This indicates that $\mathrm{H}_{2} \mathrm{O}_{2}$ mainly regulates the activation state of Rubisco, possibly through the action of Rubisco enzyme (Jiang et al. 2012). $\mathrm{H}_{2} \mathrm{O}_{2}$ treatments also significantly increased the photochemical efficiency of PSII $\left(\Phi_{\mathrm{PSII}}\right)$. $\Phi_{\mathrm{PSII}}$ is determined by photochemical quenching coefficient $\left(\mathrm{q}_{\mathrm{P}}\right)$ and maximum quantum yield of PS II $\left(\mathrm{F}_{\mathrm{v}} / \mathrm{F}_{\mathrm{m}}\right)$. The inductions of $\Phi_{\text {PSII }}$ by $\mathrm{H}_{2} \mathrm{O}_{2}$ were mainly attributed to qP but not related to $\mathrm{F}_{\mathrm{v}} / \mathrm{F}_{\mathrm{m}}$ (Jiang et al. 2012). It was reported that $\mathrm{q}_{\mathrm{P}}$ is controlled by the demand for ATP and NADPH in the Calvin cycle (Nogues and Baker 2000). The increased activity of the Calvin cycle induced by $\mathrm{H}_{2} \mathrm{O}_{2}$, therefore, could have contributed to the higher value of $\mathrm{q}_{\mathrm{p}}$.

Table 1. Effect of $\mathrm{H}_{2} \mathrm{O}_{2}$ on various photosynthetic traits in different plants.

\begin{tabular}{|c|c|c|c|}
\hline $\begin{array}{l}\text { Mode of } \mathrm{H}_{2} \mathrm{O}_{2} \\
\text { application }\end{array}$ & Plant species & Response & Reference \\
\hline Exogenous & Brassica juncea & Increased net photosynthesis $\left(P_{\mathrm{N}}\right), g_{\mathrm{s}}$, and $C_{\mathrm{i}}$ & Khan et al. 2016 \\
\hline Foliar spray & Vigna unguiculata & Improved $P_{\mathrm{N}}$ and quantum yield of PSII & Hasan et al. 2016 \\
\hline Foliar spray & Vigna radiata & $\begin{array}{l}\text { Improved photosynthesis and related attributes } \\
\left(P_{\mathrm{N}}, C_{\mathrm{i}} \text {, and } g_{\mathrm{s}} \text { values }\right)\end{array}$ & Fariduddin et al. 2014 \\
\hline Pretreated seedlings & Oryza sativa & Improved quantum yield of PSII & Uchida et al. 2002 \\
\hline Exogenous & Oryza sativa & $\begin{array}{l}\text { Regulated } P_{\mathrm{N}} \text { and higher activities of } \\
\text { phosphoenolpyruvate carboxylase }\end{array}$ & Ren et al. 2014 \\
\hline Exogenous & $\begin{array}{l}\text { Syzygium } \\
\text { samarangense }\end{array}$ & Increased $P_{\mathrm{N}}$ & Khandaker et al. 2012 \\
\hline Exogenous & Tagetes erecta & $\begin{array}{l}\left.\text { Increased photochemical quenching coefficient ( } \mathrm{q}_{\mathrm{P}}\right) \text {, } \\
\text { leading to transfer of more excited light-energy to } \\
\text { PSII reaction centre }\end{array}$ & Liao et al. 2012 \\
\hline Foliar spray & Cucumis sativus & $\begin{array}{l}\left.\text { Enhanced the photochemical efficiency of PSII ( } \Phi_{\text {PSII }}\right) \\
\text { and } q_{P}\end{array}$ & Jiang et al. 2012 \\
\hline Pretreatment of seed & Triticum aestivum & Increased $P_{\mathrm{N}}$ & He et al. 2009 \\
\hline Pretreatment of seeds & Triticum aestivum & Photosynthetic pigments and $P_{\mathrm{N}}$ increased & Ashfaque et al. 2014 \\
\hline Foliar spray & Glycine $\max$ & Increased the $P_{\mathrm{N}}, E$, and $g_{\mathrm{s}}$ & Ishibashi et al. 2011 \\
\hline Seed soaking & Vigna radiata & Enhanced $P_{\mathrm{N}}, E$, and $g_{\mathrm{s}}$ & Khan et al. 2015 \\
\hline Foliar spray & Zea mays & Improved the $P_{\mathrm{N}}, E$, and $g_{\mathrm{s}}$, and $C_{\mathrm{i}}$ & Gondim et al. 2013 \\
\hline Exogenous & Vigna radiata & $\begin{array}{l}\text { Induced generation of NO in the guard cells } \\
\text { and other cell }\end{array}$ & Lum et al. 2002 \\
\hline
\end{tabular}

\section{Hydrogen peroxide, oxidative stress and antioxidant system}

Reactive oxygen species (ROS) are continuously generated during various metabolic processes in mitochondria, chloroplast, peroxisomes, and cytoplasm which disturb normal metabolism through damage of lipids, proteins, and nucleic acids when produced in excess (Hernandez et al. 2001, Ahmad et al. 2010, Anjum et al. 2015). Plants throughout their life are prone to oxidative damage induced by environmental factors due to their sessile nature (Hippeli and Elstner 1996). In addition to this, various abiotic stress factors can also lead to overproduction and accumulation of $\operatorname{ROS}\left(\mathrm{H}_{2} \mathrm{O}_{2}\right.$, superoxide anion, and hydroxyl radicals; Becana et al. 1998, Noctor and Foyer 1998, Gill and Tuteja 2010, Das and Roychoudhury 2014), generating oxidative stress (Das and Roychoudhury 2014, Mostofa et al. 2014, Nahar et al. 2014). One of the mechanisms actively employed by plants to overcome oxidative stress is activation of antioxidants. Plants have evolved various enzymatic and non-enzymatic antioxidant systems that are involved in protecting plants against oxidative stress (Pastori and Foyer 2002, Foyer and Noctor 2005). Catalase (CAT), ascorbate peroxidase (APX), dehydroascorbate reductase (DHAR), monodehydroascorbate reductase (MDHAR), superoxide dismutase (SOD), glutathione peroxidase (GPX), glutathione reductase (GR) are the key antioxidant enzymes that constitute major defence system against ROS (Payton et al. 2001, Fan and Huang 2012, Jahan and Anis 2014). SOD form the first line of defence against ROS, dismutating superoxide to $\mathrm{H}_{2} \mathrm{O}_{2}$, while APX, GPX, and CAT subsequently detoxify $\mathrm{H}_{2} \mathrm{O}_{2}$. The detoxification of $\mathrm{H}_{2} \mathrm{O}_{2}$ through APX involves a series of events occurring during ascorbate-glutathione cycle (AsA-GSH cycle). Among the non-enzymatic antioxidants GSH and ascorbate play a key role in biological system which include regulation of gene performance (Wingate et al. 1988, May et al. 1998, Krika et al. 2012, Kapoor et al. 2015), working as a precursor in the synthesis of phytochelatin and an important component of AsA-GSH cycle. Stress-tolerant plants have higher activities of antioxidant enzymes, including CAT, POX, SOD, and GR (Pinhero et al. 1997, Zhang et al. 1995). 
Studies with transgenic plants that overexpress antioxidant enzymes also substantiate the importance of the antioxidant system for stress tolerance (Holmberg and Bülow 1998). Pretreatment with $\mathrm{H}_{2} \mathrm{O}_{2}$ has been shown to protect maize seedling from chilling injury by induction of peroxidases and mitochondrial catalase (Prasad et al. 1994a, Prasad et al. 1994b). $\mathrm{H}_{2} \mathrm{O}_{2}$ is also implicated as a part of a systemic signal that sets up an acclimatory response to high-light stress in Arabidopsis (Karpinski et al. 1999). Various studies have also emphasised the role of glutathione and ascorbate in plants signalling (Baier et al. 2000, Horling et al. 2003, Foyer and Noctor 2003). A correlation between $\mathrm{H}_{2} \mathrm{O}_{2}$ and antioxidant capacity have been reported in several plant species, such as Brassica juncea (Verma et al. 2013, Khan et al. 2016) Vigna radiata (Fariduddin et al. 2014, Khan et al. 2015), soybean (Ishibashi et al. 2011), Vigna unguiculata (Hasan et al. 2016), tomato (Zhou et al. 2012, Iseri et al. 2013), cucumber (Xia et al. 2009), and maize (Gondim et al. 2013). Sofo et al. (2015) discussed the role of $\mathrm{H}_{2} \mathrm{O}_{2}$ in plants experiencing water deficit and salinity and how CAT and APX activities are regulated at a gene level under these conditions. Moreover, transgenic plants overexpressing ROS-scavenging enzymes, such as SOD (Alscher et al. 2002), APX (Wang et al. 1999), GR (Foyer et al. 1995), and GPX (Roxas et al. 1997, 2000) showed enhanced tolerance to osmotic, temperature, and photoinhibition. The accumulation of proline is also reported to play a significant role in decreasing the photodamage of thylakoid membranes by scavenging the superoxide radicals (Ashraf and Foolad 2007, Banu et al. 2009). $\alpha$-tocopherols, lipidsoluble antioxidants are considered as scavengers of ROS and lipid radicals in plants (Hollander-Czytko et al. 2005). Tocopherols are reflected as a major antioxidant in biomembranes, where they are involved as both antioxidant and non-antioxidant functions. They are considered general antioxidants for protecting membrane stability, including quenching or scavenging ROS as singlet oxygen. Out of four isomers of tocopherols $(\alpha-, \beta-$, $\gamma-, \delta$-) found in plants, $\alpha$-tocopherol has the maximum antioxidative activity due to the occurrence of three methyl groups in its molecular structure (Kamal-Eldin and Appelqvist 1996). Carotenoids are pigments that are common in plants and microorganisms. These lipidsoluble antioxidants play important roles in plant metabolism and oxidative-stress tolerance. Carotenoids also provide protection via quenching of toxic ROS (Gill and Tuteja 2010, Kubis et al. 2014). Glycine betaine (GB) acts as a key osmoprotectant having significant potential to alleviate harmful effect produced by a variety of abiotic stresses in many organisms including algae, fungi, cyanobacteria, animals, and some higher plants (Türkan and Demiral 2009). In response to numerous environmental stresses, mainly drought and salinity, GB is stored in chloroplasts of some plant species and likewise, reported in diverse kind of microbes (Ranganayakulu et al. 2013).

\section{Role of hydrogen peroxide in tolerance to abiotic stresses}

$\mathrm{H}_{2} \mathrm{O}_{2}$ is generated due to exposure of various stresses, and many researchers have suggested that $\mathrm{H}_{2} \mathrm{O}_{2}$ plays a key role in acclimatization and cross-tolerance (Neill et al. 2002). Therefore, endogenous $\mathrm{H}_{2} \mathrm{O}_{2}$ production has been shown to increase as a result of the chilling stress in maize seedlings, where exogenous application of $\mathrm{H}_{2} \mathrm{O}_{2}$ increased tolerance to chilling stress (Prasad et al. 1994a). The application of $\mathrm{H}_{2} \mathrm{O}_{2}$ at low concentrations improved plant tolerance to heat stress (Gao et al. 2010), chilling (Gong et al. 2001), salt stress (Azevedo Neto et al. 2005, Li et al. 2011), aluminium-induced oxidative stress (Xu et al. 2010), and heavy metal stress (Lin et al. 2004, Hu et al. 2009, Fariduddin et al. 2014, Khan et al. 2016). Hossain et al. (2015) suggested that pretreatment of seeds or seedlings with $\mathrm{H}_{2} \mathrm{O}_{2}$, or combined application of $\mathrm{H}_{2} \mathrm{O}_{2}$ and abiotic stress, protected the plants under abiotic stresses by renewal of redox-homeostasis and alleviation of oxidative loss to membranes, proteins, and lipids and by modulating stress-signalling pathways. It has been also confirmed that the pretreatment with $\mathrm{H}_{2} \mathrm{O}_{2}$ in nutrient solution induces acclimation to salt stress in rice and maize seedlings, respectively (Uchida et al. 2002, Azevedo Neto et al. 2005). There is a number of reports where the effects of $\mathrm{H}_{2} \mathrm{O}_{2}$ on various abiotic stresses have been examined but diversity exists among these observations (Table 2).

\section{Signalling of hydrogen peroxide}

$\mathrm{H}_{2} \mathrm{O}_{2}$ functions as a signalling molecule including both intracellular as well as intercellular signals in numerous processes. This is of particular interest because intercellular signal molecule needs to be transported across at least one membrane. $\mathrm{H}_{2} \mathrm{O}_{2}$ can be naturally generated in a variety of normal cell types, either constitutively or in response to various stimuli (Burdon et al. 1995). Numerous stress conditions induce production of ROS such as $\mathrm{O}_{2}{ }^{--}$and $\mathrm{H}_{2} \mathrm{O}_{2}$ in plant tissues (Desikan et al. 2003). ROS are highly reactive molecules and can oxidize all types of cellular components which leads to increase in lipid peroxidation, denaturation, and breakage of DNA strands, protein modification, and even cell death (Sharma et al. 2012, Anjum et al. 2015). Therefore, it is important to eliminate ROS to avoid low temperature or other stressinduced injuries in plants. These include heat, low temperature, ultra-violet (UV) light, pathogens, elicitors, and ozone stresses. Elevated contents of $\mathrm{H}_{2} \mathrm{O}_{2}$ have been observed during chilling stress in winter in wheat leaf where chilling temperature of $4^{\circ} \mathrm{C}$ triggered a three-fold rise in $\mathrm{H}_{2} \mathrm{O}_{2}$ concentration within 1 min (Okuda et al. 1991). Similarly, $\mathrm{H}_{2} \mathrm{O}_{2}$ contents also raise up during chilling of non-acclimated maize seedlings (Gondim et al. 2010). Moreover, $\mathrm{H}_{2} \mathrm{O}_{2}$ plays an important role in transduction of defense signals in plants and could induce gene expression and protein synthesis (Apostol et al. 1989, Burdon et al. 1995) in favour of tolerance mechanism. 
Table 2. Effect of $\mathrm{H}_{2} \mathrm{O}_{2}$ on plants under various abiotic stresses.

\begin{tabular}{|c|c|c|c|}
\hline Plant species & Type of stress & Response & Reference \\
\hline Vigna radiata & Copper & $\begin{array}{l}\text { Alleviated the toxic effects of copper stress by improving } \\
\text { the photosynthetic attributes and activity of antioxidant } \\
\text { enzymes which was reflected in better growth of plants }\end{array}$ & Fariduddin et al. 2014 \\
\hline Triticum aestivum & Salt & Improved the salt tolerance of the seedlings & Wahid et al. 2007 \\
\hline Citrus aurantium & Salt & $\begin{array}{l}\text { Alleviated salinity-induced protein carbonylation and } \\
\text { altered the accumulation levels of S-nitrosylated proteins } \\
\text { in leaf }\end{array}$ & Tanou et al. 2009 \\
\hline Tagetes erecta & Drought & $\begin{array}{l}\text { Protected the ultrastructure of mesophyll cells, improved } \\
\text { photosynthetic performance and alleviated the negative } \\
\text { effects of drought }\end{array}$ & Liao et al. 2012 \\
\hline Brassica juncea & Nickel & $\begin{array}{l}\text { Improved the toxic effects of nickel stress by improving } \\
\text { photosynthetic related attributes and induced antioxidant } \\
\text { enzymes (APX and GR) and higher GSH production }\end{array}$ & Khan et al. 2016 \\
\hline Zea mays & Water deficit & $\begin{array}{l}\text { Induced antioxidant system and nutrient relation } \\
\text { in maize plants }\end{array}$ & Ashraf et al. 2015 \\
\hline Brassica juncea & Drought & $\begin{array}{l}\text { Encouraged defence response in mustard seedlings } \\
\text { by activation of methylglyoxal detoxification pathways }\end{array}$ & Hossain and Fujita 2013 \\
\hline Zea mays & UV radiation & $\begin{array}{l}\text { Synergistically effective in promoting ethylene synthesis } \\
\text { in defense responses }\end{array}$ & Wang et al. 2006 \\
\hline Oryza sativa & $\begin{array}{l}\text { Salt and } \\
\text { heat stress }\end{array}$ & $\begin{array}{l}\text { Induced activities of ROS-scavenging enzymes and also } \\
\text { generated higher quantum yield for PSII }\end{array}$ & Uchida et al. 2002 \\
\hline Lycopersicon esculentum & Cold stress & $\begin{array}{l}\text { Root application of } \mathrm{H}_{2} \mathrm{O}_{2} \text { decreased cold induced damage } \\
\text { and improved cold response of tomato }\end{array}$ & Iseri et al. 2013 \\
\hline Tobacco & Oxidative stress & $\begin{array}{l}\text { Leaves sprayed with } \mathrm{H}_{2} \mathrm{O}_{2} \text { provided protection against } \\
\text { oxidative stress by inducing CAT, APX, and } \\
\text { guaiacol peroxidases }\end{array}$ & Gechev et al. 2002 \\
\hline Agrostis stolonifera & Heat stress & $\begin{array}{l}\text { Foliar application of } \mathrm{H}_{2} \mathrm{O}_{2} \text { induced tolerance to heat stress } \\
\text { by reducing oxidative damage }\end{array}$ & Larkindale and Huang 2004 \\
\hline $\begin{array}{l}\text { Zoysia tenuifolia } \\
\text { and Zoysia matrella }\end{array}$ & Chilling stress & Improved the tolerance to chilling stress & Wang et al. 2010 \\
\hline Zea mays & Salt stress & $\begin{array}{l}\text { Reduced the deleterious effects of salinity on } \\
\text { seedling growth }\end{array}$ & Gondim et al. 2012 \\
\hline Vigna radiata & Chilling stress & $\begin{array}{l}\text { Enhanced tolerance to chilling stress and also increased } \\
\text { the glutathione content }\end{array}$ & Yu et al. 2003 \\
\hline Vigna radiata & Cold & Induced chilling tolerance comparable to cold acclimation & Hung et al. 2007 \\
\hline $\begin{array}{l}\text { Festuca arundinacea } \\
\text { and Lolium perenne }\end{array}$ & Heat & $\begin{array}{l}\text { Increased the activities of POX, CAT, APX, GR, GPX, } \\
\text { and glutathione pool }\end{array}$ & Wang et al. 2014 \\
\hline Cucumis sativus & Heat & Affected the heat-induced alteration of DNA methylation & Cao et al. 2013 \\
\hline Lycopersicon esculentum & Low temperature & $\begin{array}{l}\text { Increased the growth characteristics, SPAD chlorophyll, } \\
\text { activities of POX, PPO and fruits yield }\end{array}$ & Orabi et al. 2015 \\
\hline Zea Mays & Osmotic stress & $\begin{array}{l}\text { Improved tolerance to osmotic stress by increasing some } \\
\text { metabolites }\end{array}$ & Terzi et al. 2014 \\
\hline Vigna radiata & Chilling & Increased the glutathione content & Yu et al. 2003 \\
\hline Triticum aestivum & Aluminium & $\begin{array}{l}\text { Aluminium-induced oxidative stress mitigation in } \\
\text { wheat seedlings }\end{array}$ & $\mathrm{Xu}$ et al. 2011 \\
\hline Triticum aestivum & Salt & $\begin{array}{l}\text { Decreased the deleterious effect of salt stress on growth } \\
\text { of wheat }\end{array}$ & Li et al. 2011 \\
\hline Phaseolus vulgaris & Drought & Enhanced the root growth and fresh mass & Abass and Mohamed 2011 \\
\hline Triticum aestivum & Drought & Improved the photosynthetic rate and antioxidant system & He et al. 2009 \\
\hline Glycine $\max$ & Drought & $\begin{array}{l}\text { Increased in the mRNA levels of d-myo-inositol } \\
\text { 3-phosphate synthase } 2 \text { (GmMIPS2) and } \\
\text { galactinol synthase (GolS) }\end{array}$ & Ishibashi et al. 2011 \\
\hline
\end{tabular}

Calcium ions and hydrogen peroxide crosstalk

$\mathrm{Ca}^{2+}$ has been implicated as a secondary messenger and it is one of the major components in the cellular signalling (Sanders et al. 1999). The influx of $\mathrm{Ca}^{2+}$ through cation channels occurs in the tonoplast, endoplasmic reticulum, and plasma membrane and generates cytosolic $\mathrm{Ca}^{2+}$ $\left[\mathrm{Ca}^{2+}\right]_{\text {cyt }}$ concentration that initiates cellular responses to a diverse range of developmental cues and environmental 
challenges (White 2000, Sanders et al. 2002). Various studies have revealed that transient variation in $\left[\mathrm{Ca}^{2+}\right]_{\mathrm{cyt}}$ plays an important role in signalling induced by various stresses (Monroy and Dhindsa 1995, Sanders et al. 1999). Cold shock induces transient increases in $\left[\mathrm{Ca}^{2+}\right]_{\text {cyt }}$ content in tobacco and Arabidopsis (Knight et al. 1991, Knight et al. 1996, Polisensky and Braam 1996, Lewis et al. 1997). In the light of above mentioned studies, it could be believed that intracellular concentration of calcium was maintained through its influx which plays a key role in the cold shock response. Further, Pei et al. (2000) suggested that both $\mathrm{Ca}^{2+}$ and $\mathrm{H}_{2} \mathrm{O}_{2}$ are involved in a signalling cascade that leads to closure of stomata in Arabidopsis. $\mathrm{H}_{2} \mathrm{O}_{2}$-activated $\mathrm{Ca}^{2+}$ channels, mediate the influx of $\mathrm{Ca}^{2+}$ in the protoplasts along with the simultaneous increase in $\left[\mathrm{Ca}^{2+}\right]_{\text {cyt }}$ in intact guard cells. However, this could be autocatalytic, because $\mathrm{H}_{2} \mathrm{O}_{2}$ production in the oxidative burst requires a constant $\mathrm{Ca}^{2+}$ influx, which activates the plasma membrane-localized NADPH oxidase (Lamb and Dixon 1997, Xing et al. 1997, Grant et al. 2000, Yang and Poovaiah 2002). Moreover, the $\left[\mathrm{Ca}^{2+}\right]_{\mathrm{cyt}}$ stimulates the calmodulin (a calcium sensor) and consequently passes the signal to a downstream target, i.e. CAT which finally downregulates $\mathrm{H}_{2} \mathrm{O}_{2}$ contents by catalysing its breakdown. The combination of $\mathrm{H}_{2} \mathrm{O}_{2}$ and $\mathrm{Ca}^{2+}$ may play essential roles in plants under both stress and stress-free conditions. Various plants, even different parts of the same plant, may have diverse modulation mechanisms. Thus, interaction between $\mathrm{H}_{2} \mathrm{O}_{2}$ and $\mathrm{Ca}^{2+}$ signalling in plants is very complex. The detailed mechanism of interaction between $\mathrm{H}_{2} \mathrm{O}_{2}$ and $\mathrm{Ca}^{2+}$ needs to be unraveled in detail.

\section{Hydrogen peroxide activation of MAPK cascade and regulation of gene expression}

$\mathrm{H}_{2} \mathrm{O}_{2}$ has been considered as a secondary messenger for gene activation in mammalian cells as well as in plants. However, in plants an increased content of $\mathrm{H}_{2} \mathrm{O}_{2}$ encourages the expression of defence as well as resistance genes (Mittler et al. 2004). $\mathrm{H}_{2} \mathrm{O}_{2}$ is also involved in modulation of many activities of signalling components, such as protein phosphatases, protein kinases (González et al. 2012), and transcription factors (TFs) (Cheng and Song 2006). $\mathrm{H}_{2} \mathrm{O}_{2}$ also communicates with other signal molecules and pathway forming part of the signalling network that controls responses downstream of $\mathrm{H}_{2} \mathrm{O}_{2}$ (Neill et al. 2002). Several studies have revealed that $\mathrm{H}_{2} \mathrm{O}_{2}$ participates in the downstream genes regulation. For example, mitogen-activated protein kinase (MAPK) cascades appear to be functional downstream of $\mathrm{H}_{2} \mathrm{O}_{2}$. MAPK in plants form a large system implicated in a number of functions, such as relay of $\mathrm{H}_{2} \mathrm{O}_{2}$ signals (Zhang et al. 2006, Xing et al. 2008). They activate Nicotiana protein kinase 1 (NPK1) in a MAPK cascade that transduces extracellular stimuli to gene expression for defence (Grant et al. 2000, Kovtun et al. 2000, Desikan et al. 2001). $\mathrm{H}_{2} \mathrm{O}_{2}$ rapidly activates MAPKs in shoots, even when applied to the roots (Capone et al. 2004). It has been reported that $\mathrm{H}_{2} \mathrm{O}_{2}$ controls seed dormancy and germination by triggering the induction of $\mathrm{ABA}$ catabolism genes (Liu et al. 2010). Zinc-finger transcription factor is generally involved in the regulation of ROSrelated defence genes. It was revealed that the ZAT7 and ZAT12 zinc-finger proteins of Arabidopsis are strongly upregulated by oxidative stress in apx knockout mutants in response to $\mathrm{H}_{2} \mathrm{O}_{2}$ and methyl viologen (MV) treatment (Rizhsky 2004). ZAT10 plays a dual role both as repressor and inducer of ROS-responsive genes under salt, drought, and osmotic stresses (Sakamoto et al. 2004, Mittler 2006). ZAT6 positively regulates tolerance to chilling, drought, and salt stress, as well as resistance to bacterial infection, by modifying ROS contents and SA-related gene expression (Shi et al. 2014).

Based on above discussion, a suggested model of $\mathrm{H}_{2} \mathrm{O}_{2}$ signalling pathway has been outlined (Fig. 1). An $\mathrm{H}_{2} \mathrm{O}_{2}$ signal may be perceived by a cell surface receptor resulting in elevated $\left[\mathrm{Ca}^{2+}\right]_{\mathrm{cyt}}$. The increased content of $\left[\mathrm{Ca}^{2+}\right]_{\mathrm{cyt}}$ may trigger a signalling protein, such as protein kinase or phosphatase, to activate a cascade thus mediating phosphorylation or dephosphorylation of a transcription factor. In addition to this, $\mathrm{H}_{2} \mathrm{O}_{2}$ may activate transcription by directly oxidising $\mathrm{H}_{2} \mathrm{O}_{2}$-responsive transcription factors via oxidation of thiols of cysteine residues in protein. The modified (activated) transcription factor moves into the nucleus, interacts with its corresponding cis-acting element on the target promoter to regulate gene expression related to cold.

\section{Hydrogen peroxide toxicity in plants}

Despite the reported signalling role of $\mathrm{H}_{2} \mathrm{O}_{2}$, its excessive concentrations in the plants may be harmful. Chen et al. (2009) confirmed that the higher concentrations of $\mathrm{H}_{2} \mathrm{O}_{2}$ caused oxidative stress; on the other hand, at low concentration it acts as a signalling molecule regulating cell growth and development, cell proliferation, cell stress response, and signal transduction (Fukao and BaileySerres 2004, Mittler et al. 2004). High concentrations of $\mathrm{H}_{2} \mathrm{O}_{2}$ can directly or indirectly oxidize ascorbic acid and glutathione pool and alter the overall redox state of the cells. Such high concentrations of $\mathrm{H}_{2} \mathrm{O}_{2}$ can also damage a number of biomolecules, such as lipids, proteins, and nucleic acids that are essential for the activity and integrity of the cells (Mittler 2002). 


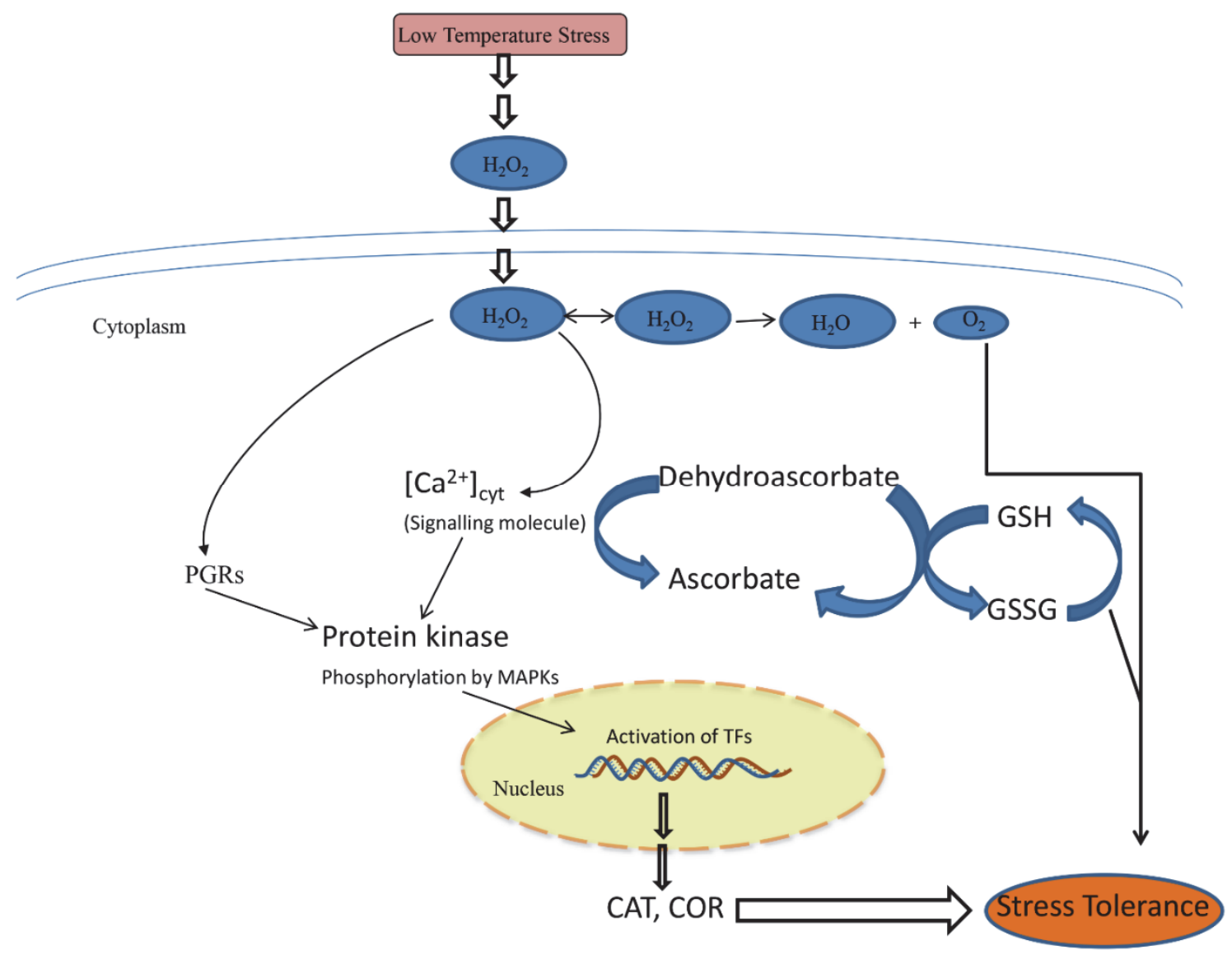

Fig. 1. A model of $\mathrm{H}_{2} \mathrm{O}_{2}$ signalling cascade for low temperature stress. $\mathrm{H}_{2} \mathrm{O}_{2}$ - hydrogen peroxide; PGRs - plant growth regulators; $\mathrm{CAT}$ - catalase; COR - cold regulated gene; GSH - glutathione; GSSG - glutathione disulphide; MAPKs - mitogen-activated protein kinases; TFs - transcription factors.

Conclusions: It has been established that $\mathrm{H}_{2} \mathrm{O}_{2}$ functions as the signalling molecule in plants depending on its concentration and crop species. It is imperative that a homeostasis should be maintained between generation and utilization of $\mathrm{H}_{2} \mathrm{O}_{2}$ inside the cells. Cells have evolved strategies to use ROS as biological signals that activate and control various stress responses at the level of gene. Therefore, it is established that $\mathrm{H}_{2} \mathrm{O}_{2}$ acts as a signalling molecules with tremendous impact on plant growth and development. Recent studies have shown that optimal $\mathrm{H}_{2} \mathrm{O}_{2}$ concentrations are important for proper plant growth, photosynthetic performance, and antioxidant activity and

\section{References}

Abass S.M., Mohamed H.I.: Alleviation of adverse effects of drought stress on common bean (Phaseolus vulgaris L.) by exogenous application of hydrogen peroxide. - Bangladesh $\mathrm{J}$. Bot. 41: 75-83, 2011.

Ahmad P., Umar S., Sharma S.: Mechanism of free radical scavenging and role of phytohormones in plants under abiotic stresses. - In: Ashraf M., Ozturk M., Ahmad M.S.A. (ed.): Plant Adaptation and Phytoremediation. Pp. 99-118. Springer, Dordrecht - Heidelberg - London - New York, Springer 2010. also for acclimation to various environmental stresses. Therefore, many of the signalling pathways mediated by $\mathrm{H}_{2} \mathrm{O}_{2}$ during various abiotic stresses have extensively been studied and still there is ample scope of additional work that could unravel the pathway mediated by $\mathrm{H}_{2} \mathrm{O}_{2}$ to confer tolerance against the various stresses. Although a significant progress has been made in the last few years, which contributed to overall understanding related to $\mathrm{H}_{2} \mathrm{O}_{2}$ mediated physiology, but many components in its signalling network are yet to be unveiled. These findings are of not only fundamental, but also of practical importance.

Ahmad P.: Oxidative Damage to Plants - Antioxidant Networks and Signaling. Pp. 65-88. Academic Press, Elsevier Inc., New York 2014.

Anjum N.A., Sofo A., Scopa A. et al.: Lipids and proteins major targets of oxidative modifications in abiotic stressed plants. - Environ. Sci. Pollut. R. 22: 4099-4121, 2015.

Alscher R.G., Erturk N., Heath L.S.: Role of superoxide dismutases (SODs) in controlling oxidative stress in plants. - J. Exp. Bot. 53: 1331-1341, 2002. 
Apel K., Hirt H.: Reactive oxygen species: metabolism, oxidative stress, and signal transduction. - Annu. Rev. Plant Biol. 55: 373-399, 2004.

Apostol I., Heinstein P.F., Low P.S.: Rapid stimulation of an oxidative burst during elicitation of cultured plant cells: role in defense and signal transduction. - Plant Physiol. 90: 109-116, 1989.

Ashfaque F., Khan M.I.R., Khan N.A.: Exogenously applied $\mathrm{H}_{2} \mathrm{O}_{2}$ promotes proline accumulation, water relations, photosynthetic efficiency and growth of wheat (Triticum aestivum L.) under salt stress. - Ann. Res. Rev. Biol. 4: 105-120, 2014.

Ashraf M., Foolad M.R.: Roles of glycine betaine and proline in improving plant abiotic stress resistance. - Environ. Exp. Bot. 59: 206-216, 2007.

Ashraf M.A., Rasheed R., Hussain I. et al.: Hydrogen peroxide modulates antioxidant system and nutrient relation in maize (Zea mays L.) under water-deficit conditions. - Arch. Agron. Soil Sci. 61: 207-523, 2015.

Azevedo-Neto A.D., Prisco J.T., Enéas-Filho J. et al.: Hydrogen peroxide pre-treatment induces salt stress acclimation in maize plants. - J. Plant Physiol. 162: 1114-1122, 2005.

Baier M., Noctor G., Foyer C.H. et al.: Antisense suppression of 2-cys peroxiredoxin in Arabidopsis thaliana specifically enhances the activites and expression of enzymes associated with ascorbate metabolism, but not glutathione metabolism. Plant Physiol. 124: 823-832, 2000.

Banu N.A., Hoque A., Watanabe-Sugimoto M. et al.: Proline and glycinebetaine induce antioxidant defense gene expression and suppress cell death in cultured tobacco cells under salt stress. J. Plant Physiol. 166: 146-156, 2009.

Barba-Espin G., Diaz-Vivancos P., Clemente-Moreno M.J. et al.: Interaction between hydrogen peroxide and plant hormones during germination and the early growth of pea seedlings. Plant Cell Environ. 33: 981-994, 2010.

Becana M., Moran J., Iturbe-Ormaetxe I.: Iron-dependent oxygen free radical generation in plants subjected to environmental stress: toxicity and antioxidant protection. - Plant Soil 201: 137-147, 1998.

Bhattacharjee S.: An inductive pulse of hydrogen peroxide pretreatment restores redox homeostasis and mitigates oxidative membrane damage under extremes of temperature in two rice cultivars (Oryza sativa L., cultivars Ratna and SR 26B). - Plant Growth Regul. 68: 395-410, 2012.

Bhattacharyya S., Das B., Ghose T.K. et al.: Investigation on seed germination of Nyctanthes arbour-tristis (Oleraceae) in relation to the phenol content. - Seed Sci. Tech. 27: 321-327, 1999.

Burdon R.H., Alliangana D., Gill V.: Hydrogen peroxide and the proliferation of BHK-21 cell. - Free Radic. Res. 23: 471-486, 1995.

Cao Y.Y., Gao Y., Sun W.J. et al.: Role of hydrogen peroxide pretreatment in heat-induced alteration of DNA methylation in cucumber leaves. - Sci. Hortic.-Amsterdam 151: 173-183, 2013.

Capone R., Tiwari B.S., Levine A.: Rapid transmission of oxidative and nitrosative stress signals from roots to shoots in Arabidopsis. - Plant Physiol. Bioch. 42: 425-428, 2004.

Carol R.J., Dolan L.: The role of reactive oxygen species in cell growth: lessons from root hairs. - J. Exp. Bot. 57: 1829-1834, 2006.

Çavusoglu K., Kabar K.: Effects of hydrogen peroxide on the germination and early seedling growth of barley under $\mathrm{NaCl}$ and high temperature stresses. - EurAsian J. Biol. Sci. 4: 70-
79, 2010.

Chien C.T., Lin T.P.: Mechanism of hydrogen peroxide in improving the germination of Cinnamonum camphora seed. Seed Sci. Tech. 22: 231-236, 1994.

Chen X.Y., Ding X., Xu S. et al.: Endogenous hydrogen peroxide plays a positive role in the upregulation of heme oxygenase and acclimation to oxidative stress in wheat seedling leaves. - J. Integr. Plant Biol. 51: 951-960, 2009.

Cheng Y., Song C.: Hydrogen peroxide homeostasis and signaling in plant cells. - Sci. China C Life Sci. 49: 1-11, 2006.

Cheng X.X., Yu M., Zhang N. et al.: Reactive oxygen species regulate programmed cell death progress of endosperm in winter wheat (Triticum aestivum L.) under waterlogging. Protoplasma 253: 311-327, 2015.

Das K., Roychoudhury A.: Reactive oxygen species (ROS) and response of antioxidants as ROS-scavengers during environmental stress in plants. - Front. Environ. Sci. 2: 53, 2014.

Deng X.P., Cheng Y.J., Wu X.B. et al.: Exogenous hydrogen peroxide positively influences root growth and exogenous hydrogen peroxide positively influences root growth and metabolism in leaves of sweet potato seedlings. - Aust. J Crop. Sci. 6: 1572-1578, 2012.

Desikan R., Hancock J.T., Neill S.J.: Oxidative stress signalling. - In: Hirt H., Shinozaki K. (ed.): Plant Responses to Abiotic Stress. Topics in Current Genetics. Pp. 121-149, Springer, Berlin, Heidelberg, 2003.

Desikan R.S., Mackerness A.H., Hancock J.T. et al.: Regulation of the Arabidopsis transcriptome by oxidative stress. - Plant Physiol. 127: 159-172, 2001.

Dietz K.J., Mittler R., Noctor G.: Recent progress in understanding the role of reactive oxygen species in plant cell signaling. - Plant Physiol. 171: 1535-1539, 2016.

Dunand C., Crevecoeur M., Penel C.: Distribution of superoxide and hydrogen peroxide in Arabidopsis root and their influence on root development: possible interaction with peroxidases. New Phytol. 174: 332-341, 2007.

Fan Y., Huang Y.: The effective peroxidase-like activity of chitosan- functionalized $\mathrm{CoFe}_{2} \mathrm{O}_{4}$ nanoparticles for chmiluminescence sensing of hydrogen peroxide and glucose. - Analyst 137: 1225-1231, 2012.

Fariduddin Q., Khan T.A., Yusuf M.: Hydrogen peroxide mediated tolerance to copper stress in the presence of 28homobrassinolide in Vigna radiata. - Acta Physiol. Plant. 36: 2767-2778, 2014.

Fontaine O., Huault C., Pavis N. et al.: Dormancy breakage of Hordeum vulgare seeds: Effect of hydrogen peroxide and stratification on glutathione level and glutathione reductase activity. - Plant Physiol. Bioch. 32: 677- 683, 1994.

Foyer C.H., Noctor G.: Redox sensing and signalling associated with reactive oxygen in chloroplasts, peroxisomes and mitochondria. - Physiol. Plantarum 119: 355-364, 2003

Foyer C.H., Noctor G.: Oxidant and antioxidant signalling in plants: a re-evaluation of the concept of oxidative stress in a physiological context. - Plant Cell Environ. 28: 1056-1071, 2005.

Foyer C.H., Souriau N., Perret S. et al:: Over-expression of glutathione reductase but not glutathione synthetase leads to increases in antioxidant capacity and improved photosynthesis in poplar (Populus tremula $\times$ P. alba) trees. - Plant Physiol. 109: 1047-1057, 1995.

Fukao T., Bailey-Serres J.: Plant responses to hypoxia-is survival a balancing act. - Trends Plant Sci. 9: 449-456, 2004.

Gao Y., Guo Y.K., Lin S.H. et al.: Hydrogen peroxide 
pretreatment alters the activity of antioxidant enzymes and protects chloroplast ultrastructure in heat stressed cucumber leaves. - Sci. Hortic.-Amsterdam 126: 20-26, 2010.

Ge X.M., Cai H.L., Lei X. et al.: Heterotrimeric G protein mediates ethylene-induced stomatal closure via hydrogen peroxide synthesis in Arabidopsis. - Plant J. 82: 138-150, 2015.

Gechev T., Gadjev I., van Breusegem F. et al: Hydrogen peroxide protects tobacco from oxidative stress by inducing a set of antioxidant enzymes. - Cell Mol. Life Sci. 59: 708-714, 2002.

Gechev T.S., Hille J.: Hydrogen peroxide as a signal controlling plant programmed cell death. - J. Cell Biol. 8: 17-20, 2005.

Gill S.S., Tuteja N.: Reactive oxygen species and antioxidant machinery in abiotic stress tolerance in crop plants. - Plant Physiol. Bioch. 48: 909-930, 2010.

Gondim F.A., Gomes-Filho E., Costa J.H. et al.: Catalase plays a key role in salt stress acclimation induced by hydrogen peroxide pretreatment in maize. - Plant Physiol. Bioch. 56: 6271, 2012.

Gondim F.A., Miranda R.S., Gomes-Filho E. et al.: Enhanced salt tolerance in maize plants induced by $\mathrm{H}_{2} \mathrm{O}_{2}$ leaf spraying is associated with improved gas exchange rather than with nonenzymatic antioxidant system. - Theor. Exp. Plant Physiol. 25: 251-260, 2013.

Gong M., Chen B., Li Z.G. et al.: Heat-shock-induced cross adaptation to heat, chilling, drought and salt stress in maize seedlings and involvement of $\mathrm{H}_{2} \mathrm{O}_{2}$. - J. Plant Physiol. 158: 1125-1130, 2001.

González A., de los Ángeles Cabrera M., Henríquez M.J. et al.: Cross talk among calcium, hydrogen peroxide, and nitric oxide and activation of gene expression involving calmodulins and calcium-dependent protein kinases in Ulva compressa exposed to copper excess. - Plant Physiol. 158: 1451-1462, 2012.

Grant J.J., Yun B.W., Loake G.J.: Oxidative burst and cognate redox signaling reported by luciferase imaging: identification of a signal network that functions independently of ethylene, SA and Me-JA but is dependent on MAPKK activity. - Plant J. 24: 569-582, 2000.

Guzel S., Terzi R.: Exogenous hydrogen peroxide increases dry matter production, mineral content and level of osmotic solutes in young maize leaves and alleviates deleterious effects of copper stress. - Bot. Stud. 54: 26, 2013.

Hasan S.A., Irfan M., Masrahi Y.S. et al.: Growth, photosynthesis, and antioxidant response of Vigna unguiculata L. treated with hydrogen peroxide. - Cogent Food Agri. 2: 1155331, 2016.

He L., Gao Z., Li R.: Pretreatment of seed with $\mathrm{H}_{2} \mathrm{O}_{2}$ enhances drought tolerance of wheat (Triticum aestivum L.) seedlings. Afr. J. Biotech. 8: 6151-6157, 2009.

Hernández J.A., Ferrer M.A., Jiménez A. et al.: Antioxidant systems and $\mathrm{O}_{2}^{-} / \mathrm{H}_{2} \mathrm{O}_{2}$ production in the apoplast of pea leaves. Its relation with salt-induced necrotic lesions in minor veins. Plant Physiol. 127: 817-831, 2001.

Hernández-Barrera A., Velarde-Buendía A., Zepeda I. et al.: Hyper, a hydrogen peroxide sensor, indicates the sensitivity of the Arabidopsis root elongation zone to aluminum treatment. Sensors 15: 855-867, 2015.

Hippeli S., Elstner E.F.: Mechanisms of oxygen activation during plant stress: biochemical effects of air pollutants. - J. Plant Physiol. 148: 249-257, 1996.

Holländer-Czytko J., Grabowski I., Sandorf K. et al.: Tocopherol content and activities of tyrosine aminotransferase and cystine lyase in Arabidopsis under stress conditions. - J. Plant Physiol.
162: 767-770, 2005.

Holmberg N., Bülow L.: Improving stress tolerance in plants by gene transfer. - Trends Plant Sci. 3: 61-66, 1998.

Horling F., Lamkemeyer P., König J. et al:: Divergent light-, ascorbate- and oxidative stress-dependent regulation of expression of the peroxiredoxin gene family in Arabidopsis. Plant Physiol. 131: 317-325, 2003.

Hossain M.A., Fujita M.: Hydrogen peroxide priming stimulates drought tolerance in mustard (Brassica juncea L.) seedlings. Plant Gene Trait. 4: 109-123, 2013.

Hossain M.A., Bhattacharjee S., Armin S.M. et al.: Hydrogen peroxide priming modulates abiotic oxidative stress tolerance: insights from ROS detoxification and scavenging. - Front. Plant Sci. 6: 420, 2015.

$\mathrm{Hu}$ Y., Ge Y., Zhang C. et al.: Cadmium toxicity and translocation in rice seedlings are reduced by hydrogen peroxide pretreatment. - Plant Growth Regul. 59: 51-61, 2009.

Hung S.H., Wang C.C., Ivanov S.V. et al.: Repetition of hydrogen peroxide treatment induces a chilling tolerance comparable to cold acclimation in mung bean. - J. Am. Soc. Hortic. Sci. 132: 770-776, 2007.

Hung S.H., Yu C.W., Lin C.H.: Hydrogen peroxide functions as a stress signal in plants. - Bot. Bull. Acad. Sci. 46: 1-10, 2005.

Işeri O.D., Körpe D.A., Sahin F.I. et al.: Hydrogen peroxide pretreatment of roots enhanced oxidative stress response of tomato under cold stress. - Acta Physiol. Plant. 35: 1905-1913, 2013.

Ishibashi Y., Yamaguchi H., Yuasa T. et al.: Hydrogen peroxide spraying alleviates drought stress in soybean plants. - J. Plant Physiol. 168: 1562-1567, 2011.

Jahan A.A., Anis M.: Changes in antioxidative enzymatic responses during acclimatization of in vitro raised plantlets of Cardiospermum halicacabum L. against oxidative stress. - J. Plant Physiol. Pathol. 4: 2, 2014.

Jiang Y., Cheng F., Zhou Y. et al.: Hydrogen peroxide functions as a secondary messenger for brassinosteroids-induced $\mathrm{CO}_{2}$ assimilation and carbohydrate metabolism in Cucumis sativus. - J. Zhejiang Univ.-Sci. B 13: 811-823, 2012.

Kamal-Eldin L.A., Appelqvist.: The chemistry and antioxidant properties of tocopherols and tocotrienols. - Lipids 31: 671701, 1996.

Kapoor D., Sharma R., Handa N. et al.: Redox homeostasis in plants under abiotic stress: role of electron carriers, energy metabolism mediators and proteinaceous thiols. - Front. Environ. Sci. 3: 13, 2015.

Karpinski S., Reynolds H., Karpinska B. et al.: Systemic signaling in response to excess excitation energy in Arabidopsis. Science 284: 654-657, 1999.

Karuppanapandian T., Moon J.C., Kim C. et al.: Reactive oxygen species in plants: their generation signal transduction, and scavenging mechanisms. - Aust. J. Crop Sci. 5: 709, 2011.

Katzman, L.S., Taylor A.G., Langhans R.W.: Seed enhancements to improve spinach germination. - HortScience 36: 979981, 2001.

Khan T.A., Yusuf M., Fariduddin Q.: Seed treatment with $\mathrm{H}_{2} \mathrm{O}_{2}$ modifies net photosynthetic rate and antioxidant system in mung bean (Vigna radiata L. Wilczek) plants. - Israel J. Plant Sci. 62: 167-175, 2015.

Khan M.I.R., Khan N.A., Masood A. et al.: Hydrogen peroxide alleviates nickel-inhibited photosynthetic responses through increase in use-efficiency of nitrogen and sulfur, and glutathione production in mustard. - Front. Plant Sci. 7: 44, 2016. 
Khandaker M.M., Boyce A.N., Osman N.: The influence of hydrogen peroxide on the growth, development and quality of wax apple (Syzygium samarangense, [Blume] Merrill \& L.M. Perry var. jambu madu) fruits. - Plant Physiol. Bioch. 53: 101$110,2012$.

Knight H., Trewavas A.J., Knight M.R.: Cold calcium signalling in Arabidopsis involves two cellular pools and a change in calcium signature after acclimation. - Plant Cell 8: 489-503, 1996.

Knight M.R., Campbell A.K., Smith S.M. et al.: Transgenic plant aequorin reports the effects of touch and cold-shock and elicitors on cytoplasmic calcium. - Nature 352: 524-526, 1991.

Kovtun Y., Chiu W.L., Tena G. et al.: Functional analysis of oxidative stress-activated mitogen-activated protein kinase cascade in plants. - P. Natl. Acad. Sci. USA 97: 2940-2945, 2000.

Krifka S., Hiller K.A., Spagnuolo G. et al.: The influence of glutathione on redox regulation by antioxidant proteins and apoptosis in macrophages exposed to 2-hydroxyethyl methacrylate (HEMA). - Biomaterials 33: 5177-5186, 2012.

Kubiś J., Floryszak-Wieczorek J., Arasimowicz-Jelonek M.: Polyamines induce adaptive responses in water deficit stressed cucumber roots. - J. Plant Res. 127: 151-158, 2014.

Lamb C., Dixon R.A.: The oxidative burst in plant disease resistance. - Annu. Rev. Plant Phys. 48: 251-275, 1997.

Larkindale J., Huang B.: Thermo tolerance and antioxidant systems in Agrostis stolonifera: involvement of salicylic acid, abscisic acid, calcium, hydrogen peroxide, and ethylene. - J. Plant Physiol. 161: 405-413, 2004.

Leshem Y., Wills R.B.H., Ku V.: Evidence for the function of the free radical gas-nitric oxide (NO) as an endogenous maturation and senescence regulating factor in higher plants. - Plant Physiol. Bioch. 36: 825-833, 1998.

Lewis B.D., Karlin-Neumann G., Davis R.W. et al.: $\mathrm{Ca}_{2}{ }^{+}-$ activated anion channels and membrane depolarizations induced by blue light and cold in Arabidopsis seedlings. - Plant Physiol. 114: 1327-1334, 1997.

Li J.T., Qiu Z.B., Zhang X.W. et al.: Exogenous hydrogen peroxide can enhance tolerance of wheat seedlings to salt stress. - Acta Physiol. Plant. 33: 835-842, 2011.

Liao W.B., Huang G.B., Yu J.H. et al.: Nitric oxide and hydrogen peroxide alleviate drought stress in marigold explants and promote its adventitious root development. - Plant Physiol. Bioch. 58: 6-15, 2012.

Lin Q., Chen Y., Wang Z. et al.: Study on the possibility of hydrogen peroxide pretreatment and plant system to remediate soil pollution. - Chemosphere 57: 1439-1447, 2004.

Liu X., Xing D., Li L. et al.: Rapid determination of seed vigor based on the level of superoxide generation during early imbibitions. - Photoch. Photobio. Sci. 6: 767-774, 2007.

Liu X.M., Kim K.E., Kim K.C. et al.: Cadmium activates Arabidopsis MPK3 and MPK6 via accumulation of reactive oxygen species. - Phytochemistry 71: 614-618, 2010.

Lum H.K., Butt Y.K.C., Lo S.C.L.: Hydrogen peroxide induces a rapid production of nitric oxide in mung bean (Phaseolus aureus). - Nitric Oxide 6: 205-213, 2002.

Ma F., Wang L.J., Li J.L. et al.: Interaction between HY1 and $\mathrm{H}_{2} \mathrm{O}_{2}$ in auxin-induced lateral root formation in Arabidopsis. Plant Mol. Biol. 85: 49-61. 2014.

May M.J., Vernoux T., Leaver C. et al.: Glutathione homeostasis in plants: implications for environmental sensing and plant development. - J. Exp. Bot. 49: 649-667, 1998.

Mittler R., Vanderauwera S., Gollery M. et al.: Reactive oxygen gene network of plants. - Trends Plant Sci. 9: 490-498, 2004.

Mittler R.: Oxidative stress, antioxidants and stress tolerance. Trends Plant Sci. 7: 405-410, 2002.

Mittler R., Vanderauwera S., Suzuki N. et al.: ROS signaling: the new wave? - Trends Plant Sci. 16: 300-309, 2011.

Mittler R.: Abiotic stress, the field environment and stress combination. - Trends Plant Sci. 11: 15-19, 2006.

Monroy A.F., Dhindsa R.S.: Low temperature signal transduction: induction of cold acclimation-specific genes of alfalfa by calcium at $25^{\circ} \mathrm{C}$. - Plant Cell 7: 321-331, 1995.

Morita S., Kaminaka H., Masumura T. et al.: Induction of rice cytosolic ascorbate peroxidase mRNA by oxidative stress: the involvement of hydrogen peroxide in oxidative stress signalling. - Plant Cell Physiol. 40: 417-422, 1999.

Mostofa M.G., Seraj Z.I., Fujita M.: Exogenous sodium nitroprusside and glutathione alleviate copper toxicity by reducing copper uptake and oxidative damage in rice (Oryza sativa L.) seedlings. - Protoplasma 251: 1373-1386, 2014.

Müller K., Linkies A., Vreeburg R.A.M. et al.: In vivo cell wall loosening by hydroxyl radicals during cross seed germination and elongation growth. - Plant Physiol. 150: 1855-1865, 2009.

Nahar K., Hasanuzzaman M., Alam M.M. et al.: Exogenous glutathione confers high temperature stress tolerance in mung bean (Vigna radiata L.) by modulating antioxidant defense and methylglyoxal detoxification system. - Environ. Exp. Bot. 112: 44-54, 2015.

Neill S.J., Desikan R., Clarke A. et al.: Hydrogen peroxide and nitric oxide as signalling molecules in plants. - J. Exp. Bot. 53: 1237-1247, 2002.

Neill S.J., Desikan R., Hancock J.: Hydrogen peroxide signaling. - Curr. Opin. Plant Biol. 5: 388-395, 2002.

Noctor G., Foyer C.: Ascorbate and GSH: keeping active oxygen under control. - Annu. Rev. Plant Phys. 49: 249-279, 1998.

Noctor G., Mhamdi A., Foyer C.H.: The roles of reactive oxygen metabolism in drought: not so cut and dried. - Plant Physiol. 164: 1636-1648, 2014.

Nogues S., Baker N.R.: Effects of drought on photosynthesis in Mediterranean plants grown under enhanced UV-B radiation. - J. Exp. Bot. 51: 1309-1317, 2000.

Ogawa K., Iwabuchi M.: A mechanism for promoting the germination of Zinnia elegans seeds by hydrogen peroxide. Plant Cell Physiol. 42: 286-291, 2001.

Okuda T., Matsuda Y., Yamanaka A. et al.: Abrupt increase in the level of hydrogen peroxide in leaves of winter wheat is caused by cold treatment. - Plant Physiol. 97: 1265-1267, 1991.

Orabi S.A., Dawood M.G., Salman S.R.: Comparative study between the physiological role of hydrogen peroxide and salicylic acid in alleviating the harmful effect of low temperature on tomato plants grown under sand-ponic culture. - Sci. Agri. 9: 49-59, 2015.

Oracz K., El-Maarouf-Bouteau H., Kranner I. et al.: The mechanisms involved in seed dormancy alleviation by hydrogen cyanide unravel the role of reactive oxygen species as key factors of cellular signalling during germination. - Plant Physiol. 150: 494-505, 2009.

Pastori G.M., Foyer C.: Common components, networks and pathways of cross-tolerance to stress. The central role of 'redox' and abscisic acid-mediated controls. - Plant Physiol. 129: 460-468, 2002.

Payton P., Webb R., Kornyeyev D. et al.: Protecting cotton photosynthesis during moderate chilling at high light intensity by increasing chloroplastic antioxidant enzyme activity. - J. 
Exp. Bot. 52: 2345-2354, 2001

Pei Z.M., Murata Y., Benning G. et al.: Calcium channels activated by hydrogen peroxide mediate abscisic acid signalling in guard cells. - Nature 406: 731-734, 2000.

Peng L.T., Jiang Y.M., Yang S.Z. et al.: Accelerated senescence of fresh-cut Chinese water chestnut tissues in relation to hydrogen peroxide accumulation. - J. Plant Phys. Mol. Biol. 31: 527-532, 2005.

Pinhero R., Rao M., Paliyath G. et al.: Changes in activities of antioxidant enzymes and their relationship to genetic and paclobutrazol-induced chilling tolerance of maize seedlings. Plant Physiol. 114: 695-704, 1997.

Polisensky D.H., Braam J.: Cold-shock regulation of the Arabidopsis TCH genes and the effects of modulating intracellular calcium levels. - Plant Physiol. 111: 1271-1279, 1996.

Prasad T., Anderson M., Martin B. et al.: Evidence for chillinginduced oxidative stress in maize seedlings and a regulatory role for hydrogen peroxide. - Plant Cell 6: 65-74, 1994a.

Prasad T., Anderson M., Stewart C.: Acclimation, hydrogen peroxide, and abscisic acid protect mitochondria against irreversible chilling injury in maize seedlings. - Plant Physiol. 105: 619-627, 1994b.

Ranganayakulu G.S., Veeranagamallaiah G., Sudhakar C.: Effect of salt stress on osmolyte accumulation in two groundnut cultivars (Arachis hypogaea L.) with contrasting salt tolerance. - Afr. J. Plant Sci. 12: 586-592, 2013.

Ren C.G., Li X., Liu X.L. et al.: Hydrogen peroxide regulated photosynthesis in C4-pepc transgenic rice. - Plant Physiol. Bioch. - 74: 218-229, 2014.

Rizhsky L., Davletova S., Liang H., Mittler R.: The zinc finger protein Zat12 is required for cytosolic ascorbate peroxidase 1 expression during oxidative stress in Arabidopsis. - J. Biol. Chem. 279: 11736-11743, 2004.

Roxas V.P., Smith R.K., Allen E.R. et al.: Overexpression of glutathione S-transferase/glutathione peroxidase enhances the growth of transgenic tobacco seedlings during stress. - Nat. Biotechnol. 15: 988-991, 1997.

Roxas V.P., Lodhi S.A., Garrett D.K. et al.: Stress tolerance in transgenic tobacco seedlings that overexpress glutathione $S$ transferase/glutathione peroxidase. - Plant Cell Physiol. 41: 1229-1234, 2000.

Sakamoto H., Maruyama K., Sakuma Y. et al.: Arabidopsis Cys2/His2-type zinc-finger proteins function as transcription repressors under drought, cold, and high-salinity stress conditions. - Plant Physiol. 136: 2734-2746, 2004.

Sanders D., Brownlee C., Harper J.F.: Communicating with calcium. - Plant Cell 11: 691-706, 1999.

Sanders D., Pelloux J., Brownlee C. et al.: Calcium at the crossroads of signalling. - Plant Cell 14: S401-S417, 2002.

Sarath G., Hou G., Hou L.M. et al.: Reactive oxygen species, $\mathrm{ABA}$ and nitric oxide interactions on the germination of warmseason C4-grasses. - Planta 226: 697-708, 2007.

Sharma P., Jha A.B., Dubey R.S. et al.: Reactive oxygen species, oxidative damage, and antioxidative defense mechanism in plants under stressful conditions. - J. Bot. 2012: 217037, 2012.

Shi H., Wang X., Ye T. et al.: The Cysteine2/Histidine2-type transcription factor ZINC FINGER OF Arabidopsis thaliana 6 modulates biotic and abiotic stress responses by activating salicylic acid-related genes and C-REPEAT-BINDING FACTOR genes in Arabidopsis. - Plant Physiol. 165: 13671379, 2014.

Sofo A., Scopa A., Nuzzaci M. et al.: Ascorbate peroxidase and catalase activities and their genetic regulation in plants subjected to drought and salinity stresses. - Int. J. Mol. Sci. 16: 13561-13578, 2015.

Tanou G., Job C., Rajjou L. et al.: Proteomics reveals the overlapping roles of hydrogen peroxide and nitric oxide in the acclimation of citrus plants to salinity. - Plant J. 60: 795-804, 2009.

Tao K.L.J., Buta J.G.: Differential effects of camptothecin and interaction with plant hormones on seed germination and seedling growth. - Plant Growth Regul. 4: 219-226, 1986.

Terzi R., Kadioglu A., Kalaycioglu E. et al.: Hydrogen peroxide pretreatment induces osmotic stress tolerance by influencing osmolyte and abscisic acid levels in maize leaves. - J. Plant Interact. 9: 559-565, 2014.

Türkan I., Demiral T.: Recent developments in understanding salinity tolerance. - Environ. Exp. Bot. 67: 2-9, 2009.

Uchida A., Jagendorf A.T., Hibino T. et al.: Effects of hydrogen peroxide and nitric oxide on both salt and heat stress tolerance in rice. - Plant Sci. 163: 515-523, 2002.

van Breusegem F., Dat J.F.: Reactive oxygen species in plant cell death. - Plant Physiol. 141: 384-390, 2006.

van Camp W.: Yield enhancement genes: seeds for growth. Curr. Opin. Biotechnol. 16: 147-153, 2005.

Vavilala S.L., Gawde K.K., Sinha M. et al.: Programmed cell death is induced by hydrogen peroxide but not by excessive ionic stress of sodium chloride in the unicellular green alga Chlamydomonas reinhardtii. - Eur. J. Phycol. 50: 422-438, 2015.

Verma K., Mehta S.K., Shekhawat G.S.: Nitric oxide (NO) counteracts cadmium induced cytotoxic processes mediated by reactive oxygen species (ROS) in Brassica juncea: cross-talk between ROS, NO and antioxidant responses. - Biometals 26: 255-269, 2013.

Wahid A., Perveen M., Gelani S. et al.: Pretreatment of seed with $\mathrm{H}_{2} \mathrm{O}_{2}$ improves salt tolerance of wheat seedlings by alleviation of oxidative damage and expression of stress proteins. - J. Plant Physiol. 164: 283-294, 2007.

Wahid A., Noreen A., Basra S.M.A. et al.: Priming-induced metabolic changes in sunflower (Helianthus annuus) achenes improve germination and seedling growth. - Bot. Stud. 49: 343-350, 2008

Wang C., Croft K.P.C., Järlfors U. et al.: Subcellular localization studies indicate that lipoxygenases 1 to 6 are not involved in lipid mobilization during soybean germination. - Plant Physiol. 120: 227-236, 1999.

Wang Y., Feng H., Qu Y. et al.: The relationship between reactive oxygen species and nitric oxide in ultraviolet- Binduced ethylene production in leaves of maize seedlings. Environ. Exp. Bot. 57: 51-61, 2006.

Wang Y., Li J., Wang J. et al.: Exogenous $\mathrm{H}_{2} \mathrm{O}_{2}$ improves the chilling tolerance of manila grass and mascarene grass by activating the antioxidative system. - Plant Growth Regul. 61: 195-204, 2010.

Wang Y., Zhang J., Li J. et al.: Exogenous hydrogen peroxide enhanced the thermotolerance of Festuca arundinacea and Lolium perenne by increasing the antioxidative capacity. Acta Physiol. Plant. 36: 2915-2924, 2014.

White P.J.: Calcium channels in higher plants. - BBABiomembranes 1465: 171-189, 2000.

Wingate V.P.M., Lawton M.A., Lamb C.J.: Glutathione causes a massive and selective induction of plant defense genes. - Plant Physiol. 87: 206-210, 1998.

Wojtyla Ł., Lechowska K., Kubala S. et al.: Different modes of hydrogen peroxide action during seed germination. - Front. Plant Sci. 7: 66, 2016. 
Xia X.J., Wang Y.J., Zhou Y.H. et al.: Reactive oxygen species are involved in brassinosteroid-induced stress tolerance in cucumber. - Plant Physiol. 150: 801-814, 2009.

Xing T., Higgins V.J., Blumwald E.: Race-specific elicitors of Cladosporium fulvum promote translocation of cytosolic components of NADPH oxidase to the plasma membrane of tomato cells. - Plant Cell 9: 249-259, 1997.

Xing Y., Jia W., Zhang J.: AtMKK1 mediates ABA-induced CAT1 expression and $\mathrm{H}_{2} \mathrm{O}_{2}$ production via AtMPK6-coupled signalling in Arabidopsis. - Plant J. 54: 440-451, 2008.

Xu F.J., Jin C.W., Liu W.J. et al.: Pretreatment with $\mathrm{H}_{2} \mathrm{O}_{2}$ alleviates aluminum-induced oxidative stress in wheat seedlings. - J. Integr. Plant Biol. 53: 44-53, 2011.

Yang T., Poovaiah B.W.: Hydrogen peroxide homeostasis: activation of plant catalase by calcium/calmodulin. - P. Natl. Acad. Sci. USA 99: 4097-4102, 2002.

Yu C.W., Murphy T.M., Lin C.H.: Hydrogen peroxide-induced chilling tolerance in mung beans mediated through ABAindependent glutathione accumulation. - Funct. Plant Biol. 30: 955-963, 2003.

Zeinalabedini M., Majourhat K., Hernández J.A. et al.: Breaking seed dormancy in long-term stored seeds from Iranian wild almond species. - Seed Sci. Tech. 37: 267-275, 2009.

Zhang A., Jiang M., Zhang J. et al.: Mitogen-activated protein kinase is involved in abscisic acid-induced antioxidant defense and acts downstream of reactive oxygen species production in leaves of maize plants. - Plant Physiol. 141: 475-487, 2006.

Zhang J., Cui S., Li J. et al.: Protoplasmic factors, antioxidant responses, and chilling resistance in maize. - Plant Physiol. Bioch. 33: 567-575, 1995.

Zhou J., Wang J., Shi K. et al.: Hydrogen peroxide is involved in the cold acclimation-induced chilling tolerance of tomato plants. - Plant Physiol. Bioch. 60: 141-149, 2012. 